(c) American Dairy Science Association, 2005.

\title{
Influence of Herd Environment on Health and Fertility and Their Relationship with Milk Production
}

\author{
J. J. Windig, M. P. L. Calus, and R. F. Veerkamp \\ Animal Sciences Group, Wageningen University and Research, \\ Division Animal Resources Development, 8200 AB Lelystad, The Netherlands
}

\begin{abstract}
High levels of milk production in dairy cattle can have negative side effects on health and fertility traits. This paper explores the relationships among milk yield, health, and fertility traits both across and within herd environments on a national scale. A total of 456,574 lactations from 3904 herds recorded from 1995 to 1999 in The Netherlands were analyzed. Herd environment was defined by 41 variables derived from production records and the annual national agricultural survey. Principal components analysis reduced this set to 4 components: intensity, defined as average production per cow, average fertility, farm size, and relative performance indicating whether herds had good (poor) health and fertility despite a high (low) production. Both fertility and health were better for some traits in high-intensity herds and for other traits in low-intensity herds. In high-intensity herds, somatic cell count (SCC) levels were lower, drops in production occurred more often, and first service took place earlier but with lower success. High fertility occurred more often in herds located on sandy soils and in those that had lower SCC levels, had fewer drops in production and higher cow survival. On large farms, drops in production were less frequent and fertility was somewhat better. The within-herd analysis showed that the relationship of milk yield with health and fertility was stronger in herds with high production, fertility, or both. In herds with poor relative performance, there was no difference in production levels between animals with good health or fertility and those with poor health or fertility.
\end{abstract}

(Key words: milk yield, health, fertility, herd environment)

Abbreviation key: $\mathbf{C I V}=$ calving interval, $\mathbf{D F S}=$ days to first service, DFLS = days from first to last service, DLS = days to last service, $\mathbf{F S C}=$ first service concep-

Received June 15, 2004.

Accepted September 23, 2004.

Corresponding author: Jack J. Windig; e-mail: jack.windig@ wur.nl. tion, $\mathbf{N R 5 6}=$ nonreturn at $56 \mathrm{~d}, \mathbf{P C A}=$ principal components analysis.

\section{INTRODUCTION}

Breeding for increased production in dairy cattle has negative side effects on health and fertility traits (Pryce et al., 1997; Rauw et al., 1998; Sandoe et al., 1999; Roxstrom et al., 2001). To counter these effects, new breeding goals and management tools have been advised (Neave et al., 1969; Barkema et al., 1999a; National Mastitis Council, 2001; Esslemont, 2003; Rupp and Boichard, 2003; Pryce et al., 2004; Royal and Flint, 2004). Management factors may increase health and fertility. For example, a farmer's attitude toward hygienic measures influences the incidence of mastitis (Barkema et al., 1999b), and the feeding system may influence the interval between calving and first insemination (Pryce et al., 1999). Such effects have been quantified by sending questionnaires or holding interviews to relate farmers' attitudes toward disease incidence (e.g., Bartlett et al., 1992; Barkema et al., 1998), and by applying different treatments within one experimental herd (e.g., Pryce et al., 1999). These are valuable approaches that can provide detailed answers to specific questions, but the scale is limited to the herd or group of herds analyzed, whereas animal breeding programs generally operate at a larger (e.g., national) scale.

In animal breeding, management and other environmental effects are generally accounted for by treating them as a fixed effect, often in the form of herd-yearseason effects. This adjusts results to the average environment, but ignores the effects of management and environmental effects on the genetic level of animals, or on the genetic association between milk yield and health and fertility traits. Recently, reaction norm models that use random regressions to estimate genetic parameters for each environment separately have been explored (Calus et al., 2002; Kolmodin et al., 2002; Calus and Veerkamp, 2003; Hayes et al., 2003). A further extension is to model the relationship between production and health and fertility traits across herd environments. In this paper, phenotypic relationships between production, health, and fertility are analyzed. 
The relationships between production and health and fertility traits across herds may differ from the relationship within herds. An improvement in management practices may, for example, improve both production and health, so that across herds, production and health are positively correlated. At the same time, the highest producing animals within herds may have more health problems, so that within herds, production and health are negatively correlated. This within-herd correlation may be environmentally dependent (e.g., Castillo-Juarez et al., 2000). High production may, for example, constitute a higher risk in terms of health and fertility only under suboptimal conditions, such as when cows are not fed adequately for high yield. Alternatively, high yields may cause greater physiological stress and thereby cause problems with health, fertility, or both, but these high yields may only be reached under optimal conditions.

This paper explores the relationship of milk yield with health and fertility traits across and within herd environments on a national scale. The main question is whether there is phenotypic variation in this relationship and whether this variation can be related to environmental variables. Furthermore, this analysis provides the basis for genetic analysis of variation in the relationship between production and health and fertility at a national scale. In particular, it provides information on which environmental variables are important to account for when analyzing the relationship between production and health and fertility.

\section{MATERIALS AND METHODS}

\section{Data}

The initial data set contained data from 5000 randomly selected herds with cows calving from 1996 to 1999. Data were selected so that cows had at least $75 \%$ Holstein-Friesian genes and herds had at least 50 heifers calving in this period. Herds had to participate in the national milk recording scheme, the herd classification program for conformation, and use AI. This resulted in a data set of 3902 herds with lactation testdays every 3 or 4 wk. Total number of lactations was 162,167 for heifers and 294,417 for multiparous cows.

\section{Production Traits}

Kilograms of milk and SCC were recorded on each test day. Somatic cell count was corrected for test-day by subtracting the expected test-day SCC based upon an average lactation curve of healthy animals. The average SCC lactation curve of healthy heifers and second or higher parity cows was determined from 274 herds in The Netherlands with 26,411 lactations where both clinical mastitis and SCC were recorded (De Haas et al., 2002). Production traits (kilograms of milk, fat, and protein, and fat/protein ratio) were also corrected for test day, by subtracting the expected test-day production based upon the average curve of animals with a low SCC. Low SCC was defined as an animal with a corrected SCC lower than 150,000 (for cows), or 100,000 (for heifers).

Milk production decreases during mastitis infections and periods with elevated SCC (Hortet and Seegers, 1998), which leads to a negative correlation between SCC and milk production. However, milk production in mastitis-free periods is negatively correlated with infection rates later in lactation (Ingvartsen et al., 2003). Therefore, lactations were split into periods with low SCC and periods where SCC peaked. Milk production before a peak was used to quantify production (following Windig et al., accepted). Test days with a corrected SCC below 150,000 belonged to low SCC periods; test days with a corrected SCC above 400,000 belonged to peak periods. Test days or a series of subsequent test days with intermediate corrected SCC (between 150,000 and 400,000) were defined as belonging to a low SCC period if they were not preceded or followed by a test day with a corrected SCC above 400,000 . Otherwise, they were defined as belonging to an SCC peak period. Thus, a SCC peak period was defined as a period where all test days had a corrected SCC $>150,000$, and at least one of these test days had a corrected SCC above 400,000. Milk production before an SCC peak was calculated by taking the average of the deviation of daily production from the lactation curve of healthy cows for all test days preceding an SCC peak. If no SCC peak occurred, the average of all test days in the entire lactation was taken. If the SCC peak began at the first test day of the lactation, the entire lactation was discarded.

\section{Health Traits}

Diseases are not recorded on a national scale in The Netherlands; therefore health traits were derived from lactation records. The average SCC over the whole lactation and the number of SCC peaks were used as indicators of mastitis infections. A drop in daily milk yield was used as an overall indicator of production-related conditions (Fourichon et al., 1999; Edwards and Tozer, 2004). Only drops after 100 DIM were considered, to avoid drops associated with a decrease in milk yield around the peak of the lactation curve. Drops in daily milk yield were evaluated at 3 levels: 2,4 , and $6 \mathrm{~kg}$. A drop occurred if the milk yield at a test day, corrected for lactation curve, was more than 2,4 , or $6 \mathrm{~kg}$ below the average of the 3 preceding test days. 


\section{Fertility Traits}

Seven fertility traits were recorded. Four traits related to the timing and length of insemination periods were defined. Days to first service (DFS) was the number of days between the calving date and the first insemination date, days to last service (DLS) was the number of days between the calving date and the last insemination, and days of first to last service (DFLS) was the difference between DLS and DFS. The calving interval (CIV) was the number of days between 2 consecutive calving dates. Three traits related to insemination success were defined. These were number of inseminations, first service conception (FSC), and nonreturn at $56 \mathrm{~d}$ (NR56). First service conception was scored as 0 if more than one insemination occurred and as 1 if only one insemination occurred and a next calving date was known, otherwise it was scored as missing. Nonreturn at $56 \mathrm{~d}$ was scored as 0 if the number of days between the first and second insemination was less than $56 \mathrm{~d}$, otherwise it was 1 except if no insemination dates were known in which case it was set to missing.

\section{Survival}

Survival was scored as 1 if a subsequent calving date was present, and as 0 if no subsequent calving date was present and if the number of days between the last test day of the animal and the last test day in its herd was larger than 140, and missing otherwise.

\section{Herd Environment}

The environment was characterized by 41 variables divided into 2 groups (Table 1). The first group consisted of herd characteristics derived from lactation records. These were calculated by taking the average of all animals in a herd. By taking the average of, for example, milk yield, a variable is created in which management characteristics such as feeding and milking intensity and the genetic level of the herd are reflected. The second group of variables consisted of herd characteristics derived from the annual national agricultural survey.

Principal components analysis (PCA) was used to group the environmental variables into a reduced set of variables. Discrete variables such as soil type were split into a set of binary variables for the PCA, e.g., herds on sandy soil got a value of 1 for the variable sand, and all other herds received a value of 0 . All herds in the data set had values for all environmental variables. Principal components were based on the correlation matrix of the environmental variables. Only components which each explained more than $5 \%$ of the total variance in all variables, were used in further analysis, and resulted in 4 components. Analyses were carried out with the software package GenStat (2002).

\section{Relationships of Health and Fertility with Milk Production and Environment}

Overall and within herds. To quantify the relationship of health and fertility with milk production, correlation coefficients were used. These correlations were first calculated over the whole data set. Separate correlations were calculated within herds, mainly to get an impression of their variability. For small herds these correlations are not an accurate estimation of the relationship of health and fertility with milk production, therefore results are presented only for the 53 herds with more than 100 lactations per year.

Significance levels for statistical tests require adjustment when a large number of correlation coefficients is computed. Bonferroni adjustments are generally used, but these assume that the different correlations are independent. However, many variables in this study are not. For example, the number of inseminations and DFLS will necessarily have similar correlations to milk yield because both traits measure the same. To avoid this problem, we required a significance level of 0.01 instead of 0.05 .

Relationship with herd environment. To assess the influence of herd environment on health and fertility, herds were grouped based on environmental variables. For discrete variables such as soil type this grouping is straightforward. For continuous environmental variables such as principal component scores, lactations were first ranked based on environmental values of their herd and then grouped. About 30 groups were formed for each environmental variable. If a group contained less than 1000 lactations it was merged with the next group. Correlation of group averages for health and fertility traits with the environmental variable were calculated to quantify the environmental influence on the trait itself.

Relationship with milk production within herd environments. Within each herd environment group, the correlation with milk yield was calculated for continuous variables such as DFS. For discrete variables, like survival, the difference in milk yield between lactations with and without survival was calculated. These values were then correlated to the group averages of the environmental variables to quantify the environmental influence on the relationship of milk yield with health and fertility.

\section{RESULTS}

\section{Overall Health, Fertility, and Production}

Average SCC was higher and SCC peaks were more often present in cows than in heifers (Table 2). Drops 
Table 1. Variables used to characterize the herd environments (range of values shown in parentheses).

\begin{tabular}{|c|c|c|}
\hline \multirow{2}{*}{$\begin{array}{l}\text { Production-derived parameters } \\
\text { (herd average) }\end{array}$} & \multicolumn{2}{|c|}{ National agricultural survey } \\
\hline & Continuous environmental parameters & Discrete environmental parameters \\
\hline 305 -d milk (4375 to $11,870 \mathrm{~kg}$ ) & Age of oldest head of farm ( 25 to $89 \mathrm{yr}$ ) & $\begin{array}{l}\text { Soil (sand, peat, loam, clay, sand and } \\
\text { clay, other) }\end{array}$ \\
\hline $305-\mathrm{d}$ fat (211 to $487 \mathrm{~kg})$ & Age of youngest head of farm (18 to $76 \mathrm{yr}$ ) & $\begin{array}{l}\text { Region (15 geographical regions e.g., } \\
\text { North, South-West) }\end{array}$ \\
\hline 305-d protein (167 to $408 \mathrm{~kg}$ ) & Number of full-time employees (1 to 10 ) & Presence of successor (Yes, No) \\
\hline Fat/protein ratio (1.12 to 1.48$)$ & Number of part-time employees (0 to 16 ) & Organic Farm (Yes, No) \\
\hline $\begin{array}{l}\text { Peak milk }(1.27 \text { to } 1.73 \times \text { average } \\
\text { daily production) }\end{array}$ & Family members working on farm ( 0 to 6 ) & Presence of open water (Yes, No) \\
\hline Calving date (1 Jan to $31 \mathrm{Dec}$ ) & Number of hours worked ( 40 to $587 \mathrm{~h} / \mathrm{wk}$ ) & Main profession of farmer (farmer, other) \\
\hline Survival rate (41 to $100 \%)$ & $\begin{array}{l}\text { Number of other farms within } 10 \mathrm{~km} \\
(0 \text { to } 80)\end{array}$ & $\begin{array}{l}\text { Barn type (tied, free-slatted floor, free-other } \\
\text { floor, other) }\end{array}$ \\
\hline Body condition score ( -3.04 to 2.94$)$ & Area of farm ${ }^{1}(0.2$ to $41 \mathrm{ha})$ & $\begin{array}{l}\text { Quality procedures (Yes, No for } 6 \text { quality } \\
\text { procedures) }\end{array}$ \\
\hline Days to last service ( 75 to 236 ) & Area of grassland ${ }^{1}$ ( 0 to 41 ha) & Other activities at farm (Yes, No) \\
\hline First service conception rate (9 to $92 \%$ ) & Area of feed $\operatorname{crop}^{1}$ ( 0 to 2.7 ha) & Use of liquid manure (Yes, No) \\
\hline Nonreturn rate $56 \mathrm{~d}$ (15 to $100 \%)$ & Number of heifers (2 to 67 ) & Nature reserve (Yes, No) \\
\hline SCC peak rate (1 to $76 \%)$ & Number of cows ( 3 to 182 ) & Other activities of farmer (Yes, No) \\
\hline Somatic cell score (1.23 to 4.31 ) & $\begin{array}{l}\text { Change in number of animals } 1999-2000 \\
(-86 \text { to }+56)\end{array}$ & \\
\hline Age at calving ( 832 to $2210 \mathrm{~d}$ ) & Milk quotum $^{1}(100$ to $8,250,000 \mathrm{~L})$ & \\
\hline Number of inseminations (1.18 to 4.28 ) & $\begin{array}{l}\text { NEG type }{ }^{2}(1=\text { no animals to } 8= \\
\text { specialized dairy farm })\end{array}$ & \\
\hline
\end{tabular}

${ }^{1}$ Logarithm used in principal components analysis.

${ }^{2}$ Classification of farm based on main source of income.

in milk production later in lactation were also more frequent in cows, although the difference in fertility between cows and heifers was minimal, and survival was higher in heifers. The correlation between milk production and health and fertility traits varied from -0.069 to 0.360 when analyzed over all animals (Table 2 ). All correlations with milk production were antagonistic, thus a higher production was correlated with poorer health and fertility. Correlations for heifers were lower than for multiparous cows.

\section{Herd Environment}

The first principal component (PC1) described 10.34\% of the total variation present in the environmental variables (Table 3). Its interpretation was relatively straightforward. Because variables relating to average production per cow were the most important variables, it could be interpreted as ranking herds according to the intensity of production. Some variables relating to the average fertility per cow were clearly correlated

Table 2. Average value (for discrete traits incidence) for all health and fertility variables of all animals, and their correlation with daily milk yield. Milk yield is before a SCC peak, if present, and corrected for test day.

\begin{tabular}{lccccc}
\hline & \multicolumn{2}{c}{ Mean/incidence } & & \multicolumn{2}{c}{$\begin{array}{c}\text { Correlation with daily } \\
\text { milk (kg) }\end{array}$} \\
\cline { 2 - 3 } \cline { 5 - 6 } & Parity 1 & Parity $>1$ & & Parity 1 & Parity $>1$ \\
\hline Mean SCC $(\times 1000)$ & 113 & 163 & & 0.017 & 0.066 \\
SCC peak presence & $11.0 \%$ & $25.8 \%$ & & 0.086 & 0.140 \\
2-kg milk drop & $56.9 \%$ & $68.5 \%$ & & 0.270 & 0.360 \\
4-kg milk drop & $30.0 \%$ & $40.8 \%$ & & 0.151 & 0.223 \\
6-kg milk drop & $9.1 \%$ & $15.1 \%$ & & 0.105 & 0.177 \\
Days to first service & 89.2 & 88.5 & & 0.081 & 0.091 \\
Days to last service & 130.2 & 129.7 & & 0.112 & 0.151 \\
First to last service & 41.0 & 40.9 & & 0.080 & 0.118 \\
Calving interval & 405.2 & 404.3 & & 0.082 & 0.122 \\
Number of inseminations & 2.06 & 2.06 & & 0.102 & 0.142 \\
First service conception & $46.1 \%$ & $43.9 \%$ & & -0.036 & -0.069 \\
56-d nonreturn rate & $59.5 \%$ & $59.5 \%$ & & -0.032 & -0.054 \\
Survival & $87.6 \%$ & $81.7 \%$ & 0.095 & 0.057 \\
\hline
\end{tabular}


Table 3. Results of the principal components analysis. For each principal component (PC1 to PC4), only traits with a score greater than 0.15 or less than -0.15 are given.

\begin{tabular}{|c|c|c|c|c|c|c|}
\hline & & Mos & mportar & original traits $^{1}$ & & \\
\hline & $\%$ Variation & Positive & Score & Negative & Score & Interpretation \\
\hline PC1 & 10.34 & $\begin{array}{l}\text { Protein } \\
\text { Fat } \\
\text { Milk } \\
\text { Inseminations, n } \\
\text { Area feed crop }\end{array}$ & $\begin{array}{l}0.343 \\
0.335 \\
0.324 \\
0.246 \\
0.175\end{array}$ & $\begin{array}{l}\text { NR56 } \\
\text { DFS } \\
\text { FSC } \\
\text { SCC } \\
\text { CIV } \\
\text { DLS }\end{array}$ & $\begin{array}{l}-0.303 \\
-0.269 \\
-0.246 \\
-0.200 \\
-0.175 \\
-0.166\end{array}$ & Intensity \\
\hline PC2 & 8.86 & $\begin{array}{l}\text { FSC } \\
\text { Sand } \\
\text { East } \\
\text { NR56 }\end{array}$ & $\begin{array}{l}0.262 \\
0.236 \\
0.190 \\
0.158\end{array}$ & $\begin{array}{l}\text { DFLS } \\
\text { DLS } \\
\text { Inseminations, } \mathrm{n} \\
\text { Area grass } \\
\text { CIV } \\
\text { Animals, } \mathrm{n} \\
\text { Clay } \\
\text { Age cows }\end{array}$ & $\begin{array}{l}-0.340 \\
-0.290 \\
-0.283 \\
-0.252 \\
-0.218 \\
-0.218 \\
-0.195 \\
-0.151\end{array}$ & Fertility + Geography \\
\hline PC3 & 7.20 & $\begin{array}{l}\text { Hours work } \\
\text { Employees, } \mathrm{n} \\
\text { Animals, } \mathrm{n} \\
\text { Milk quotum } \\
\text { Successor } \\
\text { Total area }\end{array}$ & $\begin{array}{l}0.371 \\
0.340 \\
0.252 \\
0.222 \\
0.215 \\
0.179\end{array}$ & & & Scale \\
\hline PC4 & 6.58 & $\begin{array}{l}\text { FSC } \\
\text { Protein } \\
\text { Milk } \\
\text { Fat } \\
\text { NR56 } \\
\text { Clay }\end{array}$ & $\begin{array}{l}0.324 \\
0.294 \\
0.294 \\
0.250 \\
0.219 \\
0.191\end{array}$ & $\begin{array}{l}\text { DFLS } \\
\text { Inseminations, } \mathrm{n} \\
\text { Sand } \\
\text { F/P ratio } \\
\text { East } \\
\text { Tied stall } \\
\text { SCC }\end{array}$ & $\begin{array}{l}-0.296 \\
-0.289 \\
-0.201 \\
-0.182 \\
-0.175 \\
-0.167 \\
-0.159\end{array}$ & Residual performance \\
\hline
\end{tabular}

${ }^{1} \mathrm{CIV}=$ Calving interval; DFS $=$ days to first service; DFLS $=$ days from first to last service; DLS = days to last service; FSC = first service conception; NR56 = nonreturn at $56 \mathrm{~d}$.

with production intensity (e.g., average number of inseminations with average $305-\mathrm{d}$ milk, fat, and protein yield varied from 0.23 to 0.26 ) whereas others were not (e.g., average DFLS to average 305-d milk yield, $\mathrm{r}=$ $-0.03)$. All fertility variables related to the number of inseminations (average number of inseminations, FSC, and NR56) correlated antagonistically with milk production. Somatic cell count, DFS, and CIV had a benign correlation with milk production. All variables with substantial correlations with production variables had high loadings for PC1. The scores for other variables were also consistent with the interpretation of production intensity for PC1. For example, organic farming had a negative score.

All fertility variables were important in PC2, together with variables indicating the geographical position. This reflected that average fertility was better in the east of the country on sandy soils. All fertility variables pointed in the same direction: a high score for PC2 indicates good fertility. The third principal component was related to the scale of the farms, because all variables related to the size of the farm, such as number of animals, total area, and number of employees had high loadings. The same variables as in PC1 were important for PC4, but here herds with a low number of inseminations despite a high production received a high score. This component was interpreted as relative performance, as it separates herds with relatively low production, poor fertility, and high SCC from herds with a high production, strong fertility, and low SCC.

\section{Relationships Within Herds}

Within herds with more than 100 animals, the correlations between milk production and health and fertility fluctuated widely (Table 4). For all traits, correlations varied from strongly negative to strongly positive. On average, correlations were somewhat antagonistic. The variation in the correlations could not be explained solely by the herd environment. The correlation between correlations of production with health and fertility traits and the herd environmental value was generally weak: on average 0.03 for positive correlations and -0.03 for negative correlations. The 2 strongest correlations were found for cows between PC1 and the correlation of milk yield with SCC-peak presence (0.21), and between number of inseminations and the correlation 
WINDIG ET AL.

Table 4. Variation in correlations of daily milk yield with health and fertility within herds. Fifty-three herds with more than 100 lactations per year were analysed.

\begin{tabular}{|c|c|c|c|c|c|c|}
\hline \multirow[b]{2}{*}{ Trait } & \multicolumn{3}{|c|}{ Heifers } & \multicolumn{3}{|c|}{ Cows } \\
\hline & Mean & Minimum & Maximum & Mean & Minimum & Maximum \\
\hline Mean SCC & 0.031 & -0.317 & 0.597 & 0.125 & -0.122 & 0.372 \\
\hline SCC peak presence & 0.102 & -0.214 & 0.654 & 0.190 & -0.071 & 0.708 \\
\hline 2-kg milk drop & 0.268 & -0.061 & 0.538 & 0.354 & -0.178 & 0.723 \\
\hline 4-kg milk drop & 0.159 & -0.059 & 0.479 & 0.219 & -0.051 & 0.600 \\
\hline 6-kg milk drop & 0.110 & -0.236 & 0.726 & 0.158 & -0.210 & 0.485 \\
\hline Days to first service & 0.128 & -0.458 & 0.708 & 0.119 & -0.048 & 0.376 \\
\hline Days to last service & 0.147 & -0.228 & 0.809 & 0.197 & -0.104 & 0.492 \\
\hline First to last service & 0.100 & -0.342 & 0.581 & 0.156 & -0.165 & 0.539 \\
\hline Calving interval & 0.121 & -0.219 & 0.487 & 0.179 & -0.062 & 0.418 \\
\hline Inseminations, $\mathrm{n}$ & 0.084 & -0.308 & 0.510 & 0.132 & -0.146 & 0.555 \\
\hline First service conception & -0.037 & -0.468 & 0.389 & -0.059 & -0.367 & 0.231 \\
\hline 56-d nonreturn rate & -0.026 & -0.313 & 0.505 & -0.048 & -0.416 & 0.253 \\
\hline Survival & 0.084 & -0.591 & 0.505 & 0.090 & -0.149 & 0.380 \\
\hline
\end{tabular}

of milk yield with DFLS (0.19). When correlations within all herds of all sizes were calculated, no obvious relationship with environmental characteristics was present, except that for the smaller herds, correlations fluctuated more widely. Correlations within herds with less than 40 lactations in a year fluctuated from -1 to +1 .

\section{Relationships of Average Health and Fertility with Herd Environments}

The relationship between a health or fertility trait and a single environmental variable was hard to interpret due to correlations with other environmental variables. For example, in herds on sandy soils, FSC was higher than in herds on clay. Herds on sandy soils, however, also were smaller on average, had lower production of milk, fat, and protein per cow, less access to open water, were located in a different region of the country, etc. Rather than dissect all of these relationships for each environmental variable, we used principal components that take account of all covariations between variables.

Average SCC. When animals were grouped according to the PCA values of their herds, both average SCC and SCC peak rate were higher in animals from low intensity farms, and poor fertility farms (Table 5). The incidence of SCC peaks dropped from around 20 and $30 \%$ in the lowest intensity farms to around 10 and $23 \%$ in the highest intensity farms for heifers and cows, respectively (Figure 1). For heifers the peak rate changed only in the lower half of the intensity range. Influence of PC2 (fertility/geography) was similar to the influence of PC1 (Figure 2). Animals from the highest fertility farms in the east had the lowest SCC peak rates, 2 to $8 \%$ for heifers, and 13 to $22 \%$ for cows. The PC3 (scale) barely influenced SCC peak rates, but had a clear influence on average SCC. The pattern for PC4 (relative performance) was similar to that for PC1 (Figure 2).

Drops in milk production. For cows, the rate of drops in milk production was lower for low intensity farms, whereas for heifers, rates were lowest in animals from intermediate intensity farms. The rate of drops in milk yield was also lower in poor fertility farms. When farms were grouped according to geography (separately from fertility) there was no relationship with SCC or milk drop traits. There was a clear correlation with scale (Table 5); drop rates were larger in large farms.

Average fertility. Apart from the obvious relationship that animals from poor fertility farms had lower fertility, there were also relationships with intensity and scale. Animals from high intensity farms had earlier first service but a lower conception rate (Table 6). The conception rate dropped from 55\% at the low intensity farms to 35 to $40 \%$ at high intensity farms, whereas DFS decreased from around 120 to just above $75 \mathrm{~d}$ (Figure 1). Animals from poor fertility farms in the west and on clay or peat had a later first service with a lower conception rate. The scale of the farms had a slight influence. On large farms, first service occurred somewhat earlier and inseminations were more successful (Figure 2). Lowest FSC rate (below 30\%) was found on farms where PC4 (relative performance) was low, thus where both production and fertility were low.

Survival. Survival was higher on high fertility farms (around 89 and 93\% for heifers and cows, respectively), and especially low on farms with low production and low insemination success (around 78 and 84\%). It was somewhat lower on intensive farms for cows (a decrease from 83 to $81 \%$ ) and for heifers on large farms (a decrease from 89 to $86 \%$ ). Trends in survival were not linear (Figure 2). Survival increased sharply in herds 
Table 5. Correlation between average principal component (PC) and average health or fertility trait of lactation groups. Lactation groups were formed according to principal component scores of herds, and contained at least 1000 lactations.

\begin{tabular}{|c|c|c|c|c|c|c|c|c|}
\hline Trait $^{1}$ & \multicolumn{2}{|c|}{ PC1 (Intensity) } & \multicolumn{2}{|c|}{ PC2 (Fertility) } & \multicolumn{2}{|c|}{ PC3 (Scale) } & \multicolumn{2}{|c|}{ PC4 (Relative performance) } \\
\hline \multicolumn{9}{|l|}{ Health } \\
\hline SCC peak & $-0.882^{*}$ & $-0.845^{*}$ & $-0.477^{*}$ & $-0.774 *$ & $0.564 *$ & $0.592^{*}$ & $-0.921 *$ & $-0.920 *$ \\
\hline Drop2 & -0.006 & $0.833^{*}$ & $-0.653^{*}$ & $-0.510 *$ & $-0.633^{*}$ & $-0.650 *$ & -0.088 & $0.495^{*}$ \\
\hline Drop4 & $-0.547^{*}$ & $0.588^{*}$ & $-0.639 *$ & $-0.714^{*}$ & $-0.534^{*}$ & $-0.621^{*}$ & -0.103 & 0.174 \\
\hline DLS & $-0.943 *$ & $-0.888 *$ & $-0.961^{*}$ & $-0.975^{*}$ & $-0.661^{*}$ & $-0.658^{*}$ & $-0.642 *$ & $-0.650 *$ \\
\hline DFLS & -0.259 & $0.713^{*}$ & $-0.985^{*}$ & $-0.977 *$ & $-0.675^{*}$ & $-0.488^{*}$ & $-0.933^{*}$ & $-0.920 *$ \\
\hline CIV & $-0.948^{*}$ & $-0.903^{*}$ & $-0.941 *$ & $-0.967 *$ & $-0.635^{*}$ & $-0.609 *$ & $-0.521^{*}$ & $-0.421^{*}$ \\
\hline Inseminations, $\mathrm{n}$ & $0.945^{*}$ & $0.963 *$ & $-0.980^{*}$ & $-0.962 *$ & $-0.722 *$ & $-0.558^{*}$ & $-0.915^{*}$ & $-0.914^{*}$ \\
\hline FSC & $-0.930^{*}$ & $-0.968^{*}$ & $0.947 *$ & $0.933^{*}$ & $0.626^{*}$ & $0.538^{*}$ & $0.954 *$ & $0.957 *$ \\
\hline NR56 & $-0.967 *$ & $-0.979 *$ & $0.888^{*}$ & $0.870^{*}$ & $0.595^{*}$ & $0.557^{*}$ & $0.896^{*}$ & $0.963^{*}$ \\
\hline
\end{tabular}

$* P<0.01$.

${ }^{1} \mathrm{DFS}=$ Days to first service DFLS = days from first to last service DLS = days to last service CIV = calving interval; FSC = first service conception; NR56 = nonreturn at $56 \mathrm{~d}$.

with high average fertility (PC2), whereas a strong decrease was observed in herds with low production and fertility (PC4).

\section{Relationships with Milk Production Within Herd Environments.}

Milk production and SCC. Daily milk production, before SCC peaks if present, was higher in animals with SCC peaks and with higher average SCC. The difference between animals with and without peaks increased from about $0.5 \mathrm{~kg}$ in low intensity farms to 2 and $2.8 \mathrm{~kg}$ in high intensity farms for heifers and cows, respectively (Figure 1). Thus, although average SCC is lower in high intensity herds, high-producing cows in these herds have a higher risk of elevated SCC levels.

There was less influence of PC2 on the relationship between SCC and milk yield. Especially in cows, the difference in daily milk production between animals with SCC peaks and animals without SCC peaks tended to be higher on high fertility farms (Figure 2). There was no clear influence of the scale of the farm on the relationship of milk yield with SCC-peak rate, but there was some influence of PC4. Especially for heifers, animals from farms with low production and low fertility showed a different relationship. Here, animals with SCC peaks had no or only a slightly higher daily milk production than animals without SCC peaks.

Milk production and drops in milk production. Drops in milk production occurred more often in cows with high milk yields. The difference in milk production between cows with and without drops was larger in high intensity farms (Table 6). The difference in milk production was not related to the average fertility or scale of the farms. Exceptions were cows from farms with both poor fertility and poor production. In these herds the difference in daily milk yield between cows with and without drops is less than in other herds.

Milk production and fertility. Animals with good fertility had lower milk yields on average than animals with poor fertility. The difference in daily milk yield between animals with a low number of inseminations and high insemination success was nearly constant over herds grouped according to intensity, fertility, and scale (Table 6). There was a slight effect of relative performance (PC4) in heifers: difference in milk production between heifers with and without first service conception dropped from around $0.7 \mathrm{~kg}$ on poor production and fertility farms to $0.3 \mathrm{~kg}$ on high production, high fertility farms. The correlation of milk yield with DLS, DFLS, and CIV is almost constant across herds grouped according to intensity and scale. For heifers the correlation between milk yield and these traits is larger on high-fertility farms. For example, for DLS it increased from 0.04 on the poorest fertility farms to around 0.10 on the highest fertility farms. Days to first service was the only fertility trait where the relationship between production and fertility clearly varied over environments. The correlation with milk yield was highest on high intensity farms, high fertility farms, and small farms. The lowest correlations (around 0) and lowest difference in milk yield between lactations with DFS $>90 \mathrm{~d}$ and DFS $<90 \mathrm{~d}$ (less than $0.5 \mathrm{~kg}$ ) were found in herds with low production and low insemination success (Figure 2). 
A

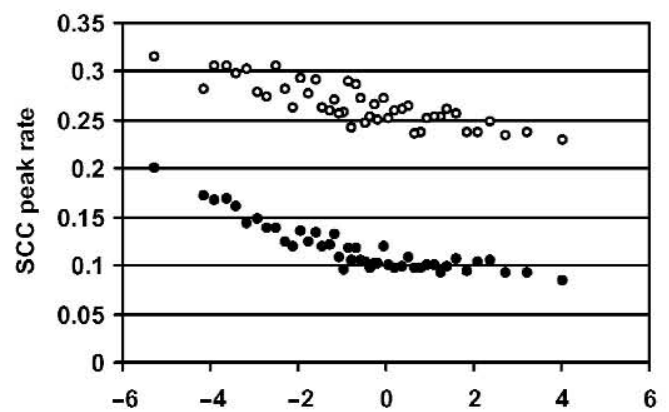

C

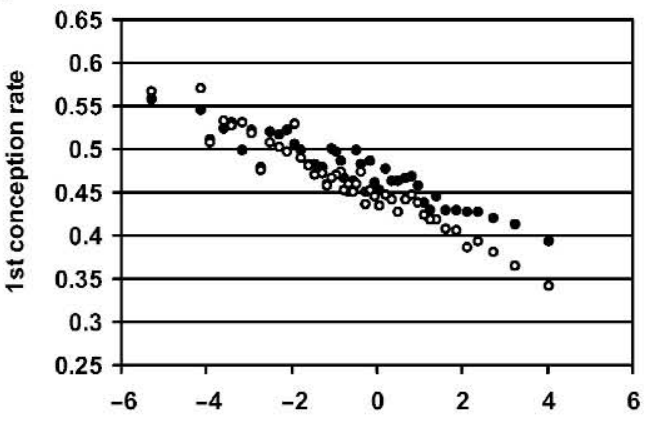

E

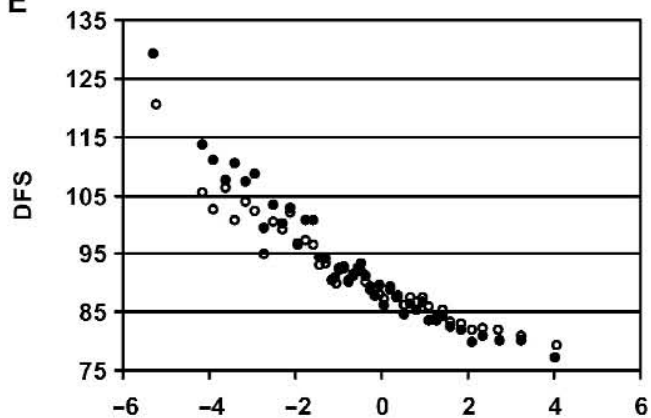

G

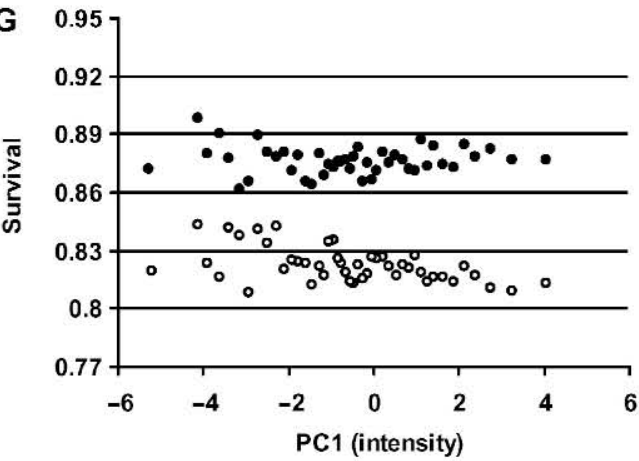

B

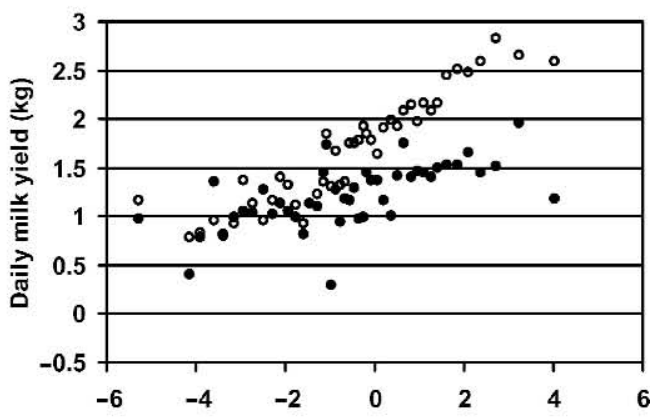

D

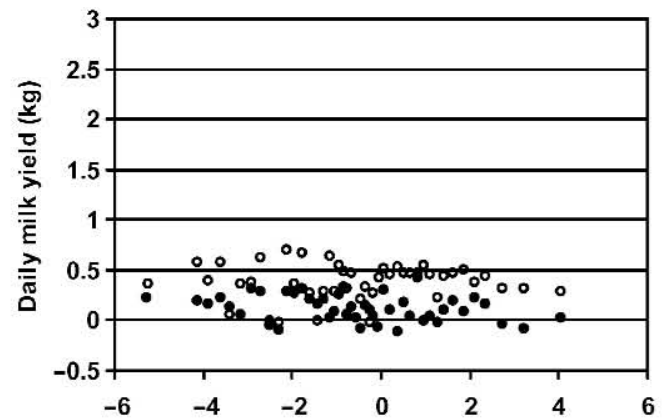

F
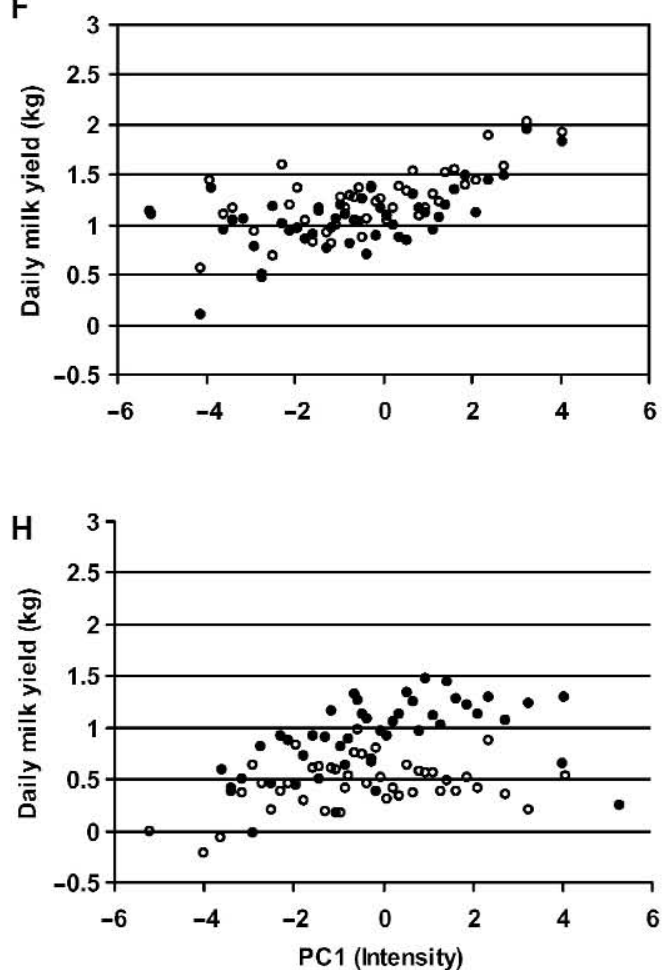

Figure 1. Relationship of health and fertility traits with average production intensity. Herds are grouped according to PC1. Each dot represents the average of $>1000$ lactations for cows $(O)$ and heifers $(\mathbf{O})$. Average health or fertility (A, C, E, G) and difference in milk production $(\mathrm{B}, \mathrm{D}, \mathrm{F}, \mathrm{H})$ between lactations with and without SCC peaks $(\mathrm{A}, \mathrm{B})$, with and without first service conception $(\mathrm{C}, \mathrm{D})$, with days to first service (DFS) over and under $100 \mathrm{~d}(\mathrm{E}, \mathrm{F})$, and with survival to next lactation and without $(\mathrm{G}, \mathrm{H})$. 
A

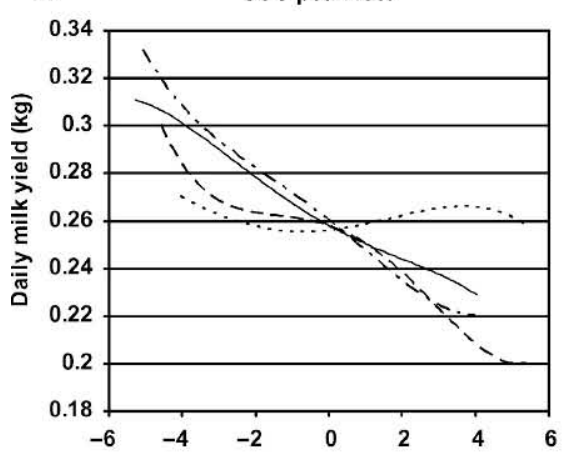

B

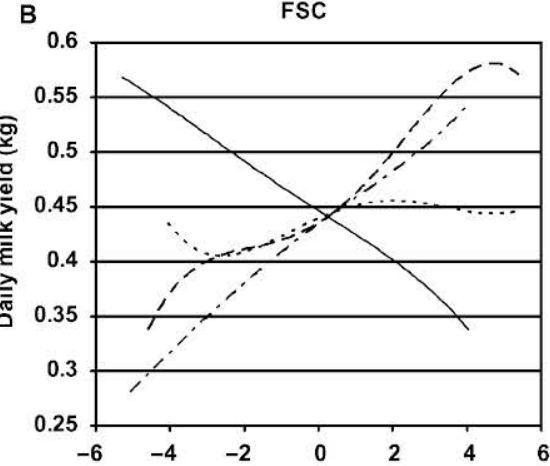

C

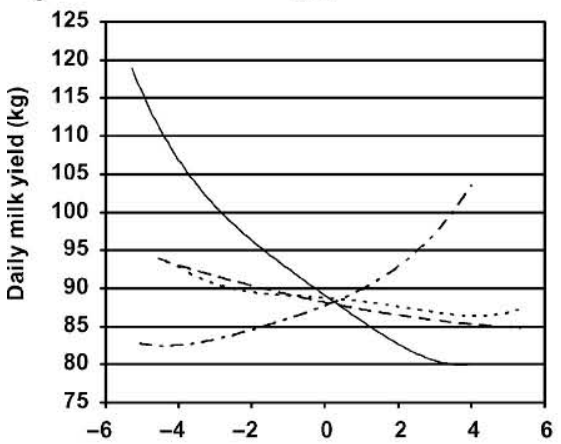

D

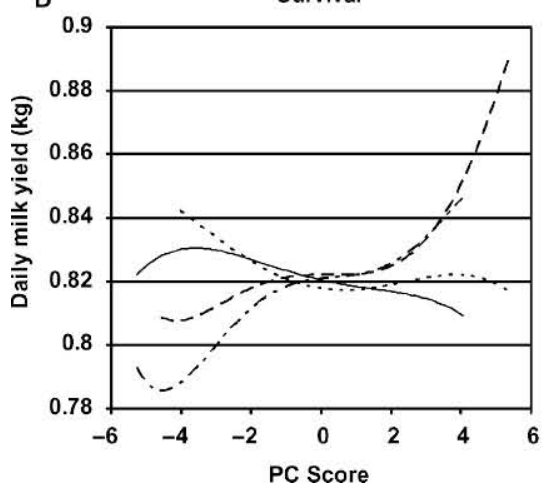

\section{E SCC peak rate}
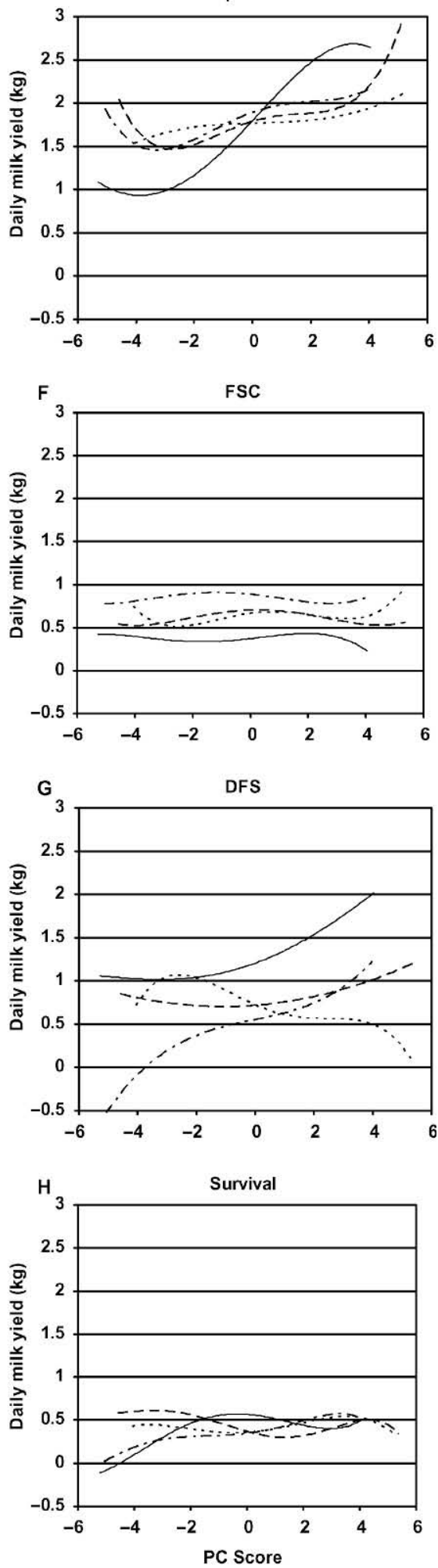

Figure 2. Trends in health and fertility traits over herd environments. Principal components scores on $\mathrm{x}$-axis: PC1 = production intensity $(-)$, PC2 $=$ fertility $(---)$, PC3 $=$ scale $(\cdots)$, and PC4 = relative performance $\left(-\cdot-\bullet_{-} \cdot-\right)$. Average health or fertility (A-D) and average difference in milk production (E-H) between lactations with and without SCC peaks (A, E), with and without first service conception (FSC)(B, F), with days to first service (DFS) over and under $100 \mathrm{~d}(\mathrm{C}, \mathrm{G})$, and with survival to next lactation and without (D, H). Lines are fourthorder polynomials through group averages (groups as in Figure 1). 
Table 6. Correlation between the influence of milk production on health and fertility traits within lactation groups and average PC scores. Influence of milk production was evaluated by difference between daily milk yield of high and low class for discrete variables, or correlation between daily milk yield and health and fertility trait for continuous variables. Lactations were grouped according to PC scores and contained at least 1000 lactations.

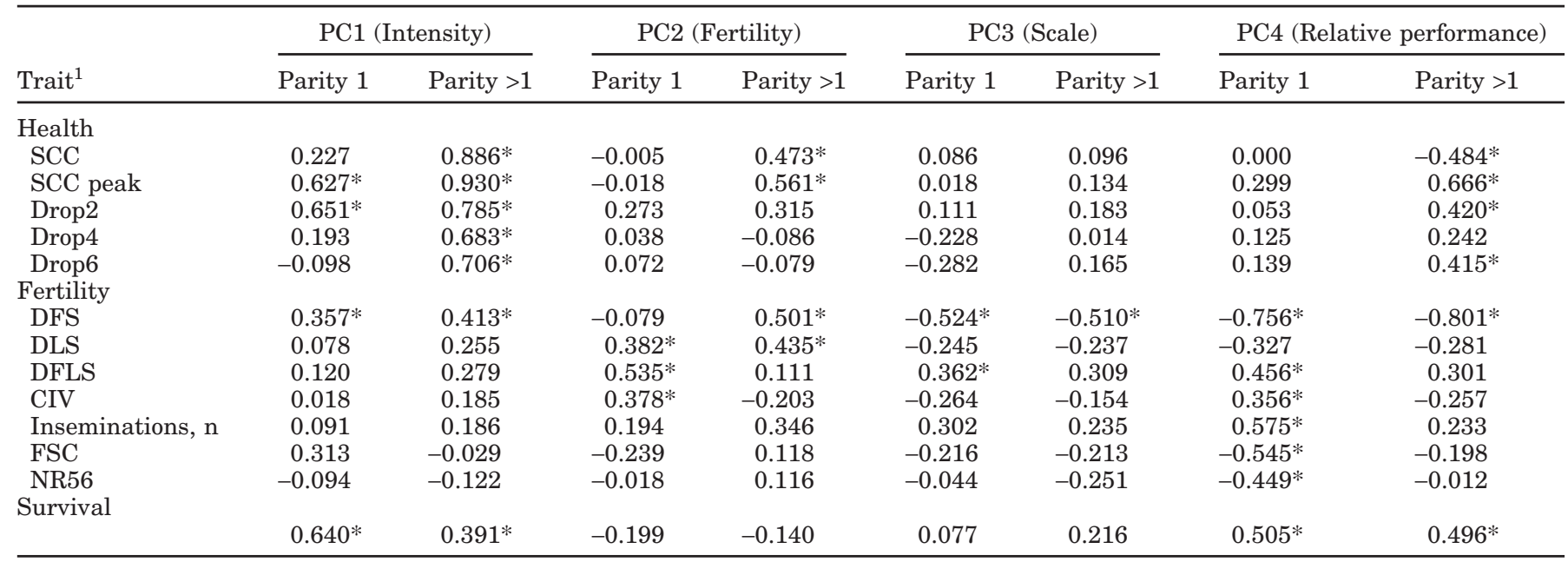

$* P<0.01$.

${ }^{1} \mathrm{DFS}=$ Days to first service; DFLS = days from first to last service; DLS = days to last service; CIV = calving interval; FSC = first service conception; NR56 $=$ nonreturn at $56 \mathrm{~d}$.

Milk production and survival. Surviving animals had higher milk production in the last lactation than culled animals. The difference in production between surviving and culled animals was almost constant across herds grouped according fertility or scale (Figure 2 ). The difference in production increased from around 0 on the lowest intensity farms to up to $1.5 \mathrm{~kg}$ (heifers) and $0.6 \mathrm{~kg}$ (cows) for intermediate- to high-intensity farms. For the highest intensity farms, however, the difference was again close to zero. Detailed inspection showed that this decrease was due to the culling of many animals that had high milk production followed by a peak in SCC.

\section{DISCUSSION}

There was not a clear-cut risk of health and fertility problems with higher milk production for all health and fertility traits. Overall, if no attention is paid to the herd environment, a higher milk yield was associated with poorer health and fertility. But within herds, this relationship was quite diverse. The 53 herds used to show this diversity are only a subset of the full data, so in the full population, diversity might be even higher. When the herds were grouped according to the herd environment, causes of this variation became apparent. Surprisingly, herds with a high intensity of production (i.e., average yield per cow) had lower SCC levels and shorter DFS on average. At the same time, the highest producing cows within these herds had higher SCC levels and longer DFS. On the other hand, both within and across herds, production was associated with a higher frequency of drops in milk production, a lower conception rate, and a higher number of inseminations.

These conflicting relationships may be explained by a change of management affecting both health/fertility traits and production. The increase in production may coincide with, for example, a better hygiene and feeding regimen, which in turn improves health and fertility levels. However, at the same time, increasing production levels may cause higher physiological stress in cows. For the highest producing cows in the high-intensity herds this stress may be so high that even the improved management is not capable of reducing mastitis levels and DFS. Consequently, the highest producing cows in these high-producing herds have the highest risk for mastitis and high DFS, whereas in herds with the low-intensity management style, mastitis levels are higher and DFS later for all cows, irrespective of production levels. Other traits, such as insemination success, are probably harder to improve by management, and these are consequently lower in high-intensity herds. Higher incidence in health and reproduction disorders in high-intensity herds was also reported in Swedish and French dairy cattle (Emanuelson and Oltenacu, 1998; Fourichon et al., 2001).

The relationship of fertility and environment was quite diverse. For fertility traits related to insemination success the relationship with intensity was antagonistic, whereas for DFS, DLS, and CIV, it was the opposite; for DFLS, there was no clear relationship. All fertility traits varied in the same way geographically: fertility 
was better in the eastern/southern regions and worse in the western/northern regions. This coincides with differences in soil (sand in east and south, clay and peat in west and north), altitude (below or at sea level in west and north, above sea level in east and south), landscape (open in west and north, woods in east and south), presence of open water (west and north), larger feed crops (east and south) etc.; although there are no important climatic differences. The actual cause of the differences is not clear, but one possibility is feed composition.

Fertility was not always related to production. In some herds both fertility and production were poor. These herds stand out with the fourth principal component. Herds with the lowest score had a low production (e.g., daily milk yield for cows $2 \mathrm{~kg}$ below average) a first conception rate below $30 \%$, a SCC-peak rate above $30 \%$, and a survival rate below $80 \%$ (Figure 1). It is also remarkable that the difference in production between healthy and fertile and unhealthy and infertile animals is lowest on these farms. Apparently all animals, whether high-producing or not, have an (almost) equal health and fertility risk. Clearly in these herds, management is far from optimal.

Health was evaluated by SCC and drops in milk production. There are many more aspects to health, but more detailed data are not available on a national scale. We have added drop in milk production to have an overall measure of production-related conditions in the latter part of lactation. Drops in milk production can be caused by diseases, but may have other causes such as sudden changes in management. Consequently, drops in milk must be seen as a measurement of the ability of cows to maintain production levels under various circumstances, including diseases. One may argue that the ability of a cow to maintain its production level under stressful conditions can also be considered indicative of general health.

The environment was characterized in this research using a principal components analysis. This reduces the number of analyses and their output considerably, and it avoids the problem that, when an effect of an environmental variable is found, it might be due to a different covariate. For example, there are slight differences in fertility among some of the soil types, but these might be due to another factor also determined geographically. In the PCA, all these factors are combined into the second $\mathrm{PC}$ and differences in fertility are better explained by the second PCA than by soil type alone. The disadvantage is that the interpretation of the principal components is not always clear. Moreover, an effect of a specific environmental variable can be overlooked. Only the general picture is distilled from all the environmental variables present.
The principal components in this research are quite similar to the results in a series of regional surveys on management styles in The Netherlands (Groen et al., 1993). In these studies the differences between farms could be related to attitudes of the farmers as investigated with questionnaires. For example, farmers for whom the economics of the farm was most important had a high score on both scale and intensity, whereas farmers for whom the animals and their breeding was most important had a high score on intensity and a low score on scale. In our research, the geographical/ fertility component is added as an important factor.

We defined the environment partly with the help of production and fertility data from the herds themselves. The idea behind this is that production and fertility in the herd is a sensitive overall measure of the management in the farm. A disadvantage is that one can end up in circular reasoning such that an increase in production is explained by an increase in average production of the herd. However, within the herds there is still variation so that one can, for example, conclude that relatively high producers at high intensity farms run a higher risk at mastitis infection than relatively low producers at the same farm. In reaction norm models, the same problem exists in that the explanatory variable is part of the variable to be explained. Calus et al. (accepted) concluded that this problem was only substantial at small farms. We grouped farms so that each group consisted of at least 1000 lactations.

The main reason for grouping herds according to their environmental variable was that estimates of, for example, infection rates or correlations between health traits and production are not reliable for small groups. There is a risk in grouping herds. Within herds, the correlation between 2 variables may be different from the correlation when herds are grouped. The conclusions in this paper are thus only valid across herds. When the management of a herd is changed so that the intensity of production increases, it is predicted that the first service conception will decrease. However, the correlations within herds as calculated for the 53 largest herds did not indicate that correlations within herds are substantially different.

In this research, environmental variation in the risk of high production at a national scale was investigated at the phenotypic level. An interesting question is what happens at the genetic level. Is the risk of mastitis infection for a cow with a high genetic value for milk yield the same in a high-intensity herd as in a lowintensity herd? Genetic analyses show that genetic differences between the levels of production are relatively constant across environments (Calus and Veerkamp, 2003) as are health and fertility traits (M. P. L. Calus, personal communication, 2004), but the genetic rela- 
tionship between the 2 may still vary. In 2 studies, the genetic correlation between SCC and milk yield were compared, and both concluded that in the high (e.g., intensive) herds the genetic correlation was stronger (Castillo-Juarez et al., 2000; Raffrenato et al., 2003). This compares well with the phenotypic correlation we found over the whole range of environments.

\section{CONCLUSIONS}

The relationship between milk production and health and fertility traits is not always the same. An increase in production does not always cause more health and fertility problems. In herds with high production per cow, SCC levels are lower and DFS is earlier, but FSC is lower and rate of drops in milk production higher. Within herds, however, high-producing cows run the highest risk, especially in herds with high production per cow. In herds with both low production per cow and low average fertility, risks are almost constant across the production range.

\section{ACKNOWLEDGMENTS}

We thank NRS (Gerben de Jong), who provided the production and fertility data set for this study, and Alterra Wageningen UR (Edo Gies), who provided data from the national agricultural survey. Yvette de Haas helped us with calculation of SCC data. Thanks are also due to Tette van der Lende and 2 anonymous reviewers who provided comments on an earlier version of the manuscript. This study was financially supported by the Ministry of Agriculture, Nature and Food (Programme 414 "maatschappelijk verantwoorde veehouderij").

\section{REFERENCES}

Barkema, H. W., Y. H. Schukken, T. Lam, M. L. Beiboer, G. Benedictus, and A. Brand. 1999a. Management practices associated with the incidence rate of clinical mastitis. J. Dairy Sci. 82:1643-1654.

Barkema, H. W., Y. H. Schukken, T. J. G. M. Lam, M. L. Beiboer, H. Wilmink, G. Benedictus, and A. Brand. 1998. Incidence of clinical mastitis in dairy herds grouped in three categories by bulk milk somatic cell counts. J. Dairy Sci. 81:411-419.

Barkema, H. W., J. D. Van der Ploeg, Y. H. Schukken, T. Lam, G. Benedictus, and A. Brands. 1999b. Management style and its association with bulk milk somatic cell count and incidence rate of clinical mastitis. J. Dairy Sci. 82:1655-1663.

Bartlett, P. C., G. Y. Miller, S. E. Lance, L. E. Heider, and C. R. Anderson. 1992. Environmental and managerial risk factors of intramammary infection with coagulase-negative staphylococci in Ohio dairy herds. Prev. Vet. Med. 14:129-142.

Calus, M. P. L., P. Bijma, and R. F. Veerkamp. 2004. Effects of data structure on the estimation of covariance functions to describe genotype by environment interactions in a reaction norm model. Genet. Sel. Evol. 36:489-508.
Calus, M. P. L., A. F. Groen, and G. de Jong. 2002. Genotype $\times$ environment interaction for protein yield in Dutch dairy cattle as quantified by different models. J. Dairy Sci. 85:3115-3123.

Calus, M. P. L., and R. F. Veerkamp. 2003. Estimation of environmental sensitivity of genetic merit for milk production traits using a random regression model. J. Dairy Sci. 86:3756-3764.

Castillo-Juarez, H., P. A. Oltenacu, R. W. Blake, C. E. McCulloch, and E. G. Cienfuegos-Rivas. 2000. Effect of herd environment on the genetic and phenotypic relationships among milk yield, conception rate, and somatic cell score in Holstein cattle. J. Dairy Sci. 83:807-814.

De Haas, Y., H. W. Barkema, and R. F. Veerkamp. 2002. The effect of pathogen-specific clinical mastitis on the lactation curve of somatic cell count. J. Dairy Sci. 85:1314-1323.

Edwards, J. L., and P. R. Tozer. 2004. Using activity and milk yield as predictors of fresh cow disorders. J. Dairy Sci. 87:524-531.

Emanuelson, U., and P. A. Oltenacu. 1998. Incidences and effects of diseases on the performance of Swedish dairy herds stratified by production. J. Dairy Sci. 81:2376-2382.

Esslemont, R. J. 2003. The costs of poor fertility and what to do about reducing them. Cattle Pract. 11:237-250.

Fourichon, C., F. Beaudeau, N. Bareille, and H. Seegers. 2001. Incidence of health disorders in dairy farming systems in western France. Livest. Prod. Sci. 68:157-170.

Fourichon, C., H. Seegers, N. Bareille, and F. Beaudeau. 1999. Effects of disease on milk production in the dairy cow: A review. Prev. Vet. Med. 41:1-35.

GenStat. 2002. GenStat for Windows Release 6.1. 6th ed. VSN International, Oxford, UK.

Groen, A. F., K. de Groot, J. D. Van der Ploeg, and D. Roep. 1993. Breeding with style: A study on the relation between socio-economic diversity and herd specific definition of breeding goals. Vakgroep veefokkerij, Vakgroep rurale sociologie landbouwuniversiteit, Wageningen. [in Dutch]

Hayes, B. J., M. Carrick, P. Bowman, and M. E. Goddard. 2003. Genotype $\times$ environment interaction for milk production of daughters of Australian dairy sires from test-day records. J. Dairy Sci. 86:3736-3744.

Hortet, P., and H. Seegers. 1998. Calculated milk production losses associated with elevated somatic cell counts in dairy cows: Review and critical discussion. Vet. Res. 29:497-510.

Ingvartsen, K. L., R. J. Dewhurst, and N. C. Friggens. 2003. On the relationship between lactational performance and health: Is it yield or metabolic imbalance that causes production diseases in dairy cattle? A position paper. Livest. Prod. Sci. 83:277-308.

Kolmodin, R., E. Strandberg, P. Madsen, J. Jensen, and H. Jorjani. 2002. Genotype by environment interaction in Nordic dairy cattle studied using reaction norms. Acta Agric. Scand. A. Anim. Sci. $52: 11-24$.

National Mastitis Council. 2001. National Mastitis Council recommended mastitis control program. Online. Available http:// www.nmconline.org/docs/NMC10steps.pdf. Accessed Oct. 28, 2004.

Neave, F. K., F. H. Dodd, R. G. Kingwill, and D. R. Westgarth. 1969. Control of mastitis in dairy herds by hygiene and management. J. Dairy Sci. 52:696-707.

Pryce, J. E., B. L. Nielsen, R. F. Veerkamp, and G. Simm. 1999. Genotype and feeding system effects and interactions for health and fertility traits in dairy cattle. Livest. Prod. Sci. 57:193-201.

Pryce, J. E., M. D. Royal, P. C. Garnsworthy, and I. L. Mao. 2004. Fertility in the high-producing dairy cow. Livest. Prod. Sci. 86:125-135.

Pryce, J. E., R. F. Veerkamp, R. Thompson, W. G. Hill, and G. Simm. 1997. Genetic aspects of common health disorders and measures of fertility in Holstein-Friesian dairy cattle. Anim. Sci. 65:353360 .

Raffrenato, E., R. W. Blake, P. A. Oltenacu, J. Carvalheira, and G. Licitra. 2003. Genotype by environment interaction for yield and somatic cell score with alternative environmental definitions. J. Dairy Sci. 86:2470-2479. 
Rauw, W. M., E. Kanis, E. N. Noordhuizen-Stassen, and F. J. Grommers. 1998. Undesirable side effects of selection for high production efficiency in farm animals: A review. Livest. Prod. Sci. $56: 15-33$.

Roxstrom, A., E. Strandberg, B. Berglund, U. Emanuelson, and J. Philipsson. 2001. Genetic and environmental correlations among female fertility traits and milk production in different parities of Swedish red and white dairy cattle. Acta Agric. Scand. A. Anim. Sci. 51:7-14.
Royal, M. D., and A. P. F. Flint. 2004. Genetic improvement of dairy cattle fertility. Cattle Pract. 12:21-29.

Rupp, R., and D. Boichard. 2003. Genetics of resistance to mastitis in dairy cattle. Vet. Res. 34:671-688.

Sandoe, P., B. L. Nielsen, L. G. Christensen, and P. Sorensen. 1999. Staying good while playing God-The ethics of breeding farm animals. Anim. Welf. 8:313-328.

Windig, J. J., M. P. L. Calus, G. de Jong, and R. F. Veerkamp. Herd variation in the association between somatic cell count patterns and milk production prior to mastitis. Livest. Prod. Sci. (accepted). 